\title{
RIMANTAS MIKNYS
}

Wilno

\section{BADANIA DRUGIEJ WOJNY ŚWIATOWEJ W INSTYTUCIE HISTORII LITWY W LATACH 2000-2005: PROBLEMY, WYNIKI, PERSPEKTYWY}

\section{Wprowadzenie}

W artykule przedstawiam badania naukowe przeprowadzone i prowadzone w Litewskim Instytucie Historii w okresie ostatnich pięciu lat. Zwracam najpierw uwage na to, co zainspirowało te badania i jak te inspiracje znalazły odzwierciedlenie w sformułowaniach problematyki badań.

Warte podkreślenia jest to, że w Instytucie w omawianym okresie były realizowane dwa programy badan, które skupiały się na tematyce drugiej wojny światowej. Pierwszy to: „Litwa w okresie drugiej wojny światowej tak zwany program „wewnętrzno-lokalny”; drugi: „Większość i mniejszość. Stosunki narodowościowe $\mathrm{w}$ regionach mieszanych etnicznie (na Wileńszczyźnie i w Litwie Wschodniej itp.) w okresie drugiej wojny światowej" - określony jako program międzynarodowy. Oba programy są wieloletnie i wieloetapowe.

Teraz kilka słów o inspiracjach takich badań. Znany jest cynizm historii jako nauki, że z największym zainteresowaniem spotykają się te momenty przeszłości, które są związane z maksymalnym wysiłkiem i nakładem sił ludzkości - wojny, rewolucje, przewroty, zawojowania itp. I to pomimo że te momenty najczęściej oznaczają masowe mordy ludności oraz inne tragedie. W historii Litwy takim momentem była druga wojna światowa, jednak ten okres jest wciąż niedostatecznie zbadany i opisany.

Problem nie polega wcale na tym, że brakuje zainteresowania tematem - można nawet powiedzieć, że w niektórych przypadkach jest go nawet zbyt dużo. Kiedy jednak to zainteresowanie przechodziło do etapu studiów 
historycznych, to śmiało można o nich powiedzieć, że są one tendencyjne, niepełne i pełne kompleksów.

Jeśli weźmiemy pod uwagę historyków, którzy obiektywnie starają się reprezentować litewską naukę historyczną, to należy stwierdzić, że na ich postawy (trudności) moralne i metodologiczne miały wpływ trzy uwarunkowania historyczne. Niejednokrotnie mówił o nich jeden z głównych inspiratorów takich badań w Instytucie, Česlovas Laurinavičius. Według niego, pierwszym uwarunkowaniem takiej sytuacji było to, że w okresie drugiej wojny światowej, a mówiąc dokładniej, w okresie okupacji hitlerowskiej, na Litwie zostali zlikwidowani Żydzi, jako historyczna i etnokulturalna część litewskiego społeczeństwa i to, że w Zagładzie uczestniczyli także Litwini, druga historyczna i etnokulturalna część litewskiego społeczeństwa. Jeśli do tej tragedii, nazywanej Holocaustem, dodamy jeszcze eliminację Polaków i Niemców (także historycznych etnokultur Litwy), to spotkamy się z założeniem, że w okresie drugiej wojny światowej na Litwie toczono jeszcze jedną wojnę - wojnę między narodami, między współobywatelami. Pomimo że takie założenie nie jest dla Litwinów miłe, to wypływa z niego drugie z wymienionych uwarunkowań: druga wojna światowa, mimo, że spowodowała wielkie straty ludnościowe narodu litewskiego, jednocześnie przyczyniła się do powiększenia jego terytorium narodowego - chyba jako jedynego z wszystkich narodów wciągniętych w tryby wojny, no, może tylko z wyjątkiem Rosjan. Pomimo to koniec drugiej wojny światowej, inaczej niż w przypadku wielu innych narodów, nie pomógł Litwinom w przywróceniu państwowości. I to byłoby trzecie z wymienionych uwarunkowań.

Nie należy się dziwić, że taki splot uwarunkowań dla zideologizowanego historyka epoki modernizmu oznacza niemożliwe do zniesienia przeciążenie wartościami.

Obecnie jednak panuje już inna epoka. Uwalnia ona historyków od zniewolenia ideologią, od stereotypów i tym samym wymusza otwarte, etyczne i kompleksowe badania historyczne. Stanowi inspirację społeczno-polityczną.

A teraz krótko o tym, kto stoi za inspiracjami badań historiograficznych zaplanowanych w Instytucie. Tutaj podeprę się jeszcze raz uwagami, wyrażonymi przez kierownika oddziału historii XX wieku dr. Česlovasa Laurinavičiusa, które wypowiedział podczas prezentacji, rejestracji i rozliczenia obu programów w Radzie Instytutu, oraz uwagami wyrażonymi przez historyków Instytutu podczas dyskusji nad obu programami. Według nich, badania i jest to jasne, nie były zaprojektowane i wykonane w pustej prze- 
strzeni. Literatura, w której w mniejszym lub większym stopniu obraz Litwy podczas drugiej wojny światowej znalazł swoje odzwierciedlenie, już w 2000 roku była na tyle obfita, że mogła inspirować formułowanie meritum problemów.

\section{Problemy}

Podczas dyskusji w Instytucie nad omawianymi problemami podkreślono, że jednym z tych problemów była analiza przyczyn wymazania Litwy oraz pozostałych państw bałtyckich z mapy świata. Zwrócono uwage, na to, że historycy z krajów zachodnich, pisząc o tym, opierają się na stwierdzeniu, że zarówno prezydent USA F. D. Roosewelt, jaki i premier Wielkiej Brytanii W. Churchill nie zgodzili się na uznanie aneksji krajów bałtyckich, że nie było, jak to się określa, „nowego Monachium” w sprawie krajów bałtyckich oraz, że cała wina za aneksję spada na barki Stalina. Z materiałów przedstawionych przez tych samych historyków wynika jednak, że Stalin podejmował swoje działania, wsłuchując się uważnie w reakcję państw zachodnich, i, że Monachium w sprawie krajów bałtyckich - choćby i niepodpisane - faktycznie istniało. Dlatego też powstaje pytanie - czy wymazania Litwy, jak i dwóch pozostałych krajów bałtyckich, w końcu nie zdeterminował wspólny interes wielkich krajów, którym państwa nadbałtyckie nie były do niczego potrzebne? Jeśli taki wspólny interes istniał, to z czego wynikał?

Drugi problem to dylemat związany z Holocaustem na Litwie oraz stosunkami litewsko-żydowskimi. W dyskusji akcentowano, że w litewskiej historiografii takiego dylematu nie ma. Tutaj główna rola przypada powstaniu czerwcowemu z 1941 roku, w czasie którego zostało odtworzone państwo litewskie, a Litwini - „odzyskali godność” ${ }^{1}$. Tymczasem w analogicznej interpretacji żydowskiej wydarzenia nazywane przez Litwinów powstaniem sa traktowane jako symbol Holocaustu, kiedy to ,,szczury wylazły ze swych jam i zaczęły napadać na ludzi" ${ }^{2}$. Liberalne zamiary przeprowadzenia badań nad Holocaustem na Litwie - tak się wydaje - przybliżyły się do wyjaśnienia wspomnianego dylematu litewsko-żydowskiego ${ }^{3}$. Pozostaje jednak otwarte

1 A. Liekis, Lietuvos laikinoji vyriausybe் (194106 22 - 08 05), Vilnius 2000.

2 А. Славинас, Гибель Помпеи, Тель-Авив 1997.

3 S. Sužiedėlis, Penkiasdešimt metu praejus: lietuviu tautos sukilimo ir laikinosios vyriausybes istorijos interpretaciju disonansai, „Metmenys”, 1991, Nr. 61; L. Truska, Ir atleisk mums mūsu tèvu bei seneliu nuodèmes (Apie holokausta Lietuvoje $1941 \mathrm{~m}$.), 
pytanie - dlaczego właśnie na Litwie Żydzi w krótkim relatywnie czasie w ciągu drugiej połowy 1941 roku - zostali totalnie wymordowani? Podczas prowadzenia badań nad tą drażliwą kwestią należy wziąć pod uwage dwa najważniejsze kryteria: horyzontalne, czyli geopolityczne i poziome, czyli moralne.

I w końcu trzeci problem jest związany z identyfikacją Litwinów, jako wspólnoty politycznej. Wiadomo, że niemiecki komisarz generalny Adrian Theodor von Renteln nie uważał Litwinów za tak zwany naród państwowy, a, w zasadzie tylko za chłopów, których dość łatwo byłoby zintegrować z narodem niemieckim ${ }^{4}$. Z drugiej strony swój zarząd komisaryczny planowali narzucić Litwinom także niektórzy politycy polscy ${ }^{5}$. Widać więc, że pozornie logiczne następstwo, czyli nastanie na Litwie rządów sowieckich komisarzy - wymaga naukowego zakwestionowania.

Opierając się na tym, co wynikało ze wspomnianych dyskusji, zostały sformułowane następujące cele i zadania badań $^{6}$ : dla programu pierwszego i w częściowo drugiego podczas ich formułowania wzięto pod uwagę, że druga wojna światowa dla Litwy była nie tylko okupacją hitlerowską, chociaż takie wyobrażenie jest dominujące. W czasie dyskusji konstatowano, że na początku wojny Litwa była państwem niepodległym, a sprawa litewskiej państwowości, jako wartości najważniejszej, powinna stać się tą główną nicią, która w programie związałaby wszystkie inne problemy oraz pomogłaby je wyjaśnić.

Postawienie tematu państwowości na pierwszym miejscu nie jest wyrazem szowinizmu. $\mathrm{Z}$ punktu widzenia analizy naukowej byłby to, jak się wydaje, najbardziej poręczny identyfikator Litwy, jako stosunkowo małe-

\footnotetext{
„Kultūros barai”, 1999, Nr. 5-6; V. Brandišauskas, Lietuviu ir žydu santykiai 1940-1941 metais, „Darbai ir Dienos”, Kaunas 1996, Nr. 2 (11); A. Eidintas, Lietuvos žydu žudyniu byla: Dokumenty ir straipsniu rinkinys, oprac. A. Eidintas. V., 2001; A. Bubnys, Mažieji Lietuvos žydu gerai ir laikinos izoliavimo stovyklos 1941-1943 m., LIM, 1999; Y. Arad, The „Final Solution” in Lithuania in the Light of German Documentation”, "Yad Vashem Studies", 1976, t. 11 (Jerusalim); Ch. Dieckmann, Der Krieg und die Ermordung der litauischen Juden, w: Nationalsocialistische Vernichtungspolitik 1939-1945: Neue Forschungen und Kontroversen, Frankfurt am Main 1998; D. Levin, „Lithuania”. Encyclopedia of the Holocaust, New York 1990, Vol. 3, p. 895-899.

4 Komunikat niemieckiego komisarza generalnego A. T. von Rentelna z roku 1942. A. Bubnys, Vokiečiu okupuota Lietuva. 1941-1945, Vilnius 1998, p. 530-539.

5 A. Bubnys, Armijos Krajovos ištakos ir ideologija Lietuvoje, w: Armija Krajova Lietuvoje, Vilnius - Kaunas 1995.

6 Zob.: LII.Lietuva Antrajame pasauliniame kare. D. 2. (2006-2010) (dr. Č. Laurinavičius) // www.istorija.lt
} 
go podmiotu politycznego w kontekście międzynarodowym i geopolitycznym, który w dużej mierze przesądził o procesach zachodzących na samej Litwie.

Podczas dzielenia tematu na czynniki zewnętrzne i wewnętrzne, zadania programu były ustalone mniej więcej w takim układzie:

1. Decyzje „wielkiej polityki” oraz jej wpływy na wydarzenia wynikające ze skutków drugiej wojny światowej, takie jak:

a) zależność geopolityczna Litwy po wojnie;

b) kształtowanie terytorium Litwy;

c) kataklizm demograficzny na Litwie;

2. Wpływ likwidacji państwa litewskiego w 1940 roku na wewnętrzne procesy polityczne, socjalne i psychologiczne.

3. Zrekonstruowanie życia wewnętrznego Litwy pod okupacją niemiecką:

a) cechy charakterystyczne polityki niemieckiej na Litwie;

b) litewski samorząd i jego cechy;

c) życie społeczno-polityczne Litwinów;

d) sytuacja innych narodów Litwy - Żydów, Polaków, Rosjan, Niemców;

e) Holocaust na Litwie;

f) kolaboracja oraz przejawy oporu;

g) cechy zbrojnego podziemia (sowieckiego, polskiego, żydowskiego);

h) powody litewskiej emigracji w latach 1944-45 oraz jej struktura socjalna.

Formułując takie same problemy dla programu drugiego, zauważono, że pomimo tego, iż konflikty międzyetniczne w okresie drugiej wojny światowej doczekały się niemało uwagi ze strony historyków, traktowano je zazwyczaj jako efekt uboczny wojny, lub jako jedną z jej konsekwencji. Takie spojrzenie znajdowało uzasadnienie w ideologicznej konfrontacji czasów zimnej wojny. Było to charakterystyczne szczególnie dla historiografii sowieckiej, która obraz wojny przedstawiała z wyraźnie zaznaczoną linią frontu: z jednej strony linii znajdowali się faszyści, a z drugiej - siły antyfaszystowskie. Z drugiej strony takie spojrzenie miało motywację metodologiczną, naświetlającą główną tragedię drugiej wojny światowej - Holocaust. Wszyscy przecież rozumieją, że gdyby nie było agresji hitlerowskiej, nie byłoby Holocaustu.

W dyskusji stwierdzono też, że w podzielonej ideologicznie interpretacji historii pozostały niedostatecznie zbadane losy innych narodów - nie jako części składowej światowych koalicji, ale jako podmiotów per se - jako podmiotów ze swoją własną refleksją celowości toczenia wojny; ze swoimi celami 
i środkami ich realizacji; w końcu, ze swoim życiem codziennym i, co jest szczególnie ważne, ze swoim systemem wartości moralnych.

Jeśli chodzi o Żydów, to zdecydowano się, że obok (przepraszam za cynizm) zbadania mechaniki Holocaustu, będą podjęte próby identyfikacji refleksji zarówno Żydów, jak i innych żyjących obok nich narodów, np. Litwinów. Tutaj zasadniczym celem jest przeanalizowanie kwestii, jak Litwini postrzegali Żydów i jak Żydzi postrzegali Litwinów. I jak ten stosunek do siebie wzajemnie zmieniał się w miare przebiegu wojny. Analogicznie należałoby dokonać przeglądu stosunków Żydów z innymi narodami - z Polakami, Białorusinami, Niemcami itd. Wyraźnie byłoby wtedy widać, jak trudno jest dotrzeć do refleksji Żydów, co związane jest z ich etnicznym zamknięciem się we własnym kręgu.

Formułując zadania zwrócono uwagę na to, że i w kwestii Polaków zauważalny jest wpływ schematów ideologicznych. Polacy, którzy, to wiedzą wszyscy, stali się pierwszą ofiarą wojny, często w literaturze historycznej są przedstawiani jako obrońcy prawomocności oraz zwolennicy powrotu do sytuacji status quo ante bellum. Taki pogląd posiada jednak zarówno silne jak i słabe strony. Wiadomo, że generał Sikorski, opierając się na wspomnianej zasadzie, żądał od Stalina zwrotu pod jurysdykcję Państwa Polskiego wszystkich obywateli Polski, w tym także Ukraińców, Żydów, Białorusinów, itd. - tych, którzy mieszkali po polskiej stronie granicy wyznaczonej przez Traktat Ryski. Z drugiej strony jednak, wiadomo przecież, że status Armii Krajowej na Wileńszczyźnie opierał się nie na zasadzie obywatelskiej, ale na selekcji narodowościowej, gdyż do tej armii byli przyjmowani tylko Polacy. Widać więc, że polska praktyka narodowościowa różniła się od ideologicznej doktryny prawnej. Można więc stwierdzić, że narodowa izolacja była charakterystyczna także dla Polaków, a nie tylko dla pozostałych narodów regionu. A to oznacza, że ich większość statystyczną w regionie można postrzegać tylko w wymiarze relatywnym.

Czy taka interpretacja jest prawidłowa - powinny pokazać badania w ramach omawianego programu.

Mówiąc o Litwinach zauważono, że należałoby zwrócić uwagę na poziom czy też adekwatność ich refleksji. Szczególnie porównując ją z refleksjami Żydów czy Polaków. Zwrócono uwagę na to, że na świadomość Litwinów wielki wpływ miały czynniki zewnętrzne: zarówno sowiecki jak i niemiecki. Mechanizm tego wpływu podobny był do zastosowanego przez Żydów, tylko, że odwrotny. Żydzi, by uniknąć poczucia bycia mniejszością, wykorzystali struktury sowieckie, Litwini natomiast - nazistowskie. Być może to właśnie 
z tego powodu stosunki między Żydami i Litwinami nabrały tak tragicznego charakteru.

Konkretne i szczegółowe badania drugiego programu powinny dać odpowiedź na pytanie, w jakim stopniu te hipotezy są trafne.

\section{Wyniki}

Co można powiedzieć o wynikach obu badań w omawianym okresie? Po pierwsze, że są świadectwem tego, iż postawione tutaj problemy są tylko częściowo przeanalizowane. Badania nad nimi wciąż nabierają tempa. Jest to związane $\mathrm{z}$ jednej strony $\mathrm{z}$ tym, że podejmowane są próby rozszerzenia kręgu ich badaczy przez udział doktorantów i organizacje konferencji międzynarodowych. Po drugie, z tworzeniem i systematyzowaniem bazy źródeł. Można więc mówić o wstępnych wynikach badań.

Godne uwagi jest to, że obok pierwszego programu „Litwa w okresie drugiej wojny światowej” przeprowadzono badania na temat „Sytuacja międzynarodowa Litwy, albo kwestia litewska na arenie międzynarodowej w okresie drugiej wojny światowej". Na ten temat zorganizowano konferencję międzynarodową, która odbyła się w Wilnie 29-30 listopada 2003 roku. W konferencji uczestniczyli naukowcy z Polski, Rosji, Niemiec, USA i Litwy. Wszystkie referaty przedstawione na konferencji zostaną opublikowane w zbiorze „Litwa w okresie drugiej wojny światowej”. Godne uwagi jest to, że została podjęta kwestia: czy wymazania Litwy, jak i dwóch pozostałych krajów bałtyckich z mapy świata nie zdeterminował wspólny interes wielkich krajów, którym państwa nadbałtyckie nie były do niczego potrzebne? Jeśli taki wspólny interes istniał, co było jego przyczyną? Na konferencji dążono nie tylko do wyjaśnienia okoliczności kryzysu istnienia krajów bałtyckich, ale i rozpatrzenia szans alternatywy dla sowieckiej aneksji, pojawiających się do chwili, gdy podczas toczącej się wojny nie skrystalizował się ostatecznie nowy układ. Na konferencji zostały omówione:

1. Sytuacja międzynarodowa krajów bałtyckich w okresie międzywojennym i okoliczności kryzysu 1939 roku.

2. Okoliczności powstania umów o wzajemnej pomocy z ZSRR w 1939 roku.

3. Identyfikacja powodów i okoliczności decyzji Kremla o aneksji krajów bałtyckich. 
4. Dylemat uznania lub nieuznania aneksji. Geneza polityki nieuznania aneksji.

5. Kwestia krajów bałtyckich w rokowaniach sowiecko-brytyjskich z lat 1941-42.

6. Możliwości akceptowania samodzielności narodów bałtyckich w niemieckiej polityce w latach 1941-44.

7. Plany odtworzenia państw Europy Środkowo-Wschodniej i kwestia krajów bałtyckich.

8. Litewsko-polska współpraca dyplomatyczna w latach 1941-1943.

9. Mozaika możliwości odtworzenia państwowości państw bałtyckich w 1944 roku.

10. Wpływ Holocaustu na los krajów bałtyckich.

Drugi temat tego programu to badania wewnętrznej sytuacji na Litwie w okresie drugiej wojny światowej. W tym kierunku znaczące badania przeprowadził Gediminas Vaskela (została wydana monografia poświęcona procesom gospodarczym na Litwie w latach 1939-19407), Rimantas Zizas (o samoobronie wsi litewskiej ${ }^{8}$, o działalności „czerwonych” partyzantów ${ }^{9}$, o losie sowieckich jeńców na Litwie pod okupacją niemiecką); Arūnas Bubnys (o tragedii Holocaustu na Litwie ${ }^{10}$, o litewskich wojskowych formacjach pronazistowskich ${ }^{11}$, o poglądach politycznych Litwinów pod okupacją niemiecką ${ }^{12}$ ); Regina Laukaityte (o aspektach wyznań religijnych w okresie

7 G. Vaskèla, Lietuva 1939-1940 metais: kursas i valstybès reguliuojama ekonomika, Vilnius: Lietuvos istorijos inst. l-kla, 2002, $266 \mathrm{~s}$.

8 R. Zizas, Vietinè savisauga (savigyna) Lietuvoje naciu Vokietijos okupacijos metais (1941-1944), „Genocidas ir rezistencija”, Vilnius 2001, nr. 2 (10), s. 44-61; 2002, nr. 1 (11), s. $69-94$.

9 R. Zizas, Žudyniu Kaniūkuose pédsakais, „Genocidas ir rezistencija”, 2002, nr. 1 (11), s. 149-165; Idem, Bakaloriškiu sunaikinimas, „Genocidas ir rezistencija”, 2002, nr. 2 (12), s. 232-246; Idem, Pacyfikacja wsi Koniuchy (Kaniūkai), „Biuletyn Historii Pogranicza”, Bialystok 2003, nr. 4, s. 33-57; Idem, Raudonuju partizanu ir Pietryči Lietuvos kaimu savisaugos ginkluoti konfliktai 1943 m., „Genocidas ir rezistencija”, 2004, nr. 1 (15), s. $138-158$; nr. 2 (16), s. 145-161.

10 Šoa (holokaustas) Lietuvoje: skaitiniai / Valstybinis Vilniaus Gaono žydų muziejus; sudarytojas Josifas Levinsonas, Vilnius 2001-2004; Holokausto istorijos tyrimai ir tautų kolektyvinè atmintis Baltijos regione: tarptautinès mokslinės konferencijos medžiaga / Vytauto Didžiojo universitetas. Politikos mokslų ir diplomatijos institutas. Europos studijų centras, Humanitarinių mokslų fakultetas. Istorijos katedra. Genocido aukų gelbejjimo tyrimų centras; [sudarytojai Klaus Fuchs, Egle Bendikaitė], Kaunas 2002, 114 s.

11 A. Bubnys, Lietuviu policijos 1 (13)-asis batalionas ir žydu žudynès 1941 m., „Genocidas ir rezistencija", 2006, nr. 2 (20), s. 31-52.

12 A. Bubnys, Nazi resistance movement in Lithuania, 1941-1944 [translation by Vijolè Arbas], Vilnius 2003, s. 211. 
wojny ${ }^{13}$ ); Mindaugas Pocius (o litewskim partyzanckim ruchu oporu przeciw sowieckiej okupacji ${ }^{14}$ ). Szczególne miejsce zajmują badania V. Stravinskiene, dotyczące opuszczenia Wileńszczyzny przez polską diasporę w latach $1944-1945^{15}$.

Ważnym aspektem tych badań było przygotowanie do druku zbiorów dokumentów, ukazujących Litwę w czasach drugiej wojny światowej. Pracownicy LIH i Moskiewskiego Instytutu Historii Społecznej (N. Liebiediewa, Č. Laurinavičius, Algimantas Kasparavičius) przygotowali i wydali tom dokumentów pod tytułem „ZSRR i Litwa w latach drugiej wojny światowej, t. 1: ZSRR i Litowskaja Respublika 1939-1941 g.", w którym ukazane zostały przygotowania i dokonanie przez Związek Radziecki aneksji i okupacji Litwy ${ }^{16}$. Planowane jest przygotowanie jeszcze jednego tomu dokumentów ukazującego stosunek Związku Radzieckiego do kwestii litewskiej w latach 1940-1945.

Oprócz tego G. Rudis przygotował do druku dziennik Zenonasa Blynasa, sekretarza generalnego Litewskiej Partii Nacjonalistycznej z lat 1941-1944 (36 arkuszy).

$\mathrm{W}$ czasie realizacji programu $\mathrm{w}$ zasadzie osiągnięto większość stawianych celów. Na przykład dodatkowo zbadano okoliczności likwidacji państwowości Litwy i pozostałych dwóch krajów bałtyckich, co wzmocniło przekonanie, że „Monachium” w sprawie krajów bałtyckich mimo wszystko ist-

13 R. Laukaitytè, Stačiatikiu Bažnyčia „naciu tarnyboje”: metropolito Sergijaus drama, w: Lietuvos istorijos metraštis, 2001 metai, 2, Vilnius, 2002, s. 149-160; Idem, Stačiatikiu vienuolynai Lietuvoje 1944-1990 m., Istorija, 2002, s. 54-63; Idem, Lietuvos Bažnyčiu misijos okupuotose SSSR dalyse 1941-1944 m., Lituanistica, 2005, nr. 3, s. 1-14; Idem, Kataliku bažnyčios padèties restitucija Lietuvoje 1941-1944 m., Lietuvos istorijos metraštis. 2005, 2, Vilnius, 2006, s. 117-134; Idem, Mykolo Krupavičiaus memorandumai sovietu ir vokiečiu valdžiai, „Lietuvos katalikų akademijos metraštis”, t. 27, Vilnius, 2005, s. $511-526$.

14 M. Pocius, Antisovietinis ginkluotas pasipriešinimas Lietuvoje 1944-1953 m.: represiniu struktūru nuostoliai ir civiliniu gyventoju netektys, Lietuvos istorijos metraštis. 1997 metai, Vilnius, 1998, s. 198-222; Idem, Antisovietinis ginkluotas pasipriešinimas ir jo slopinimas Rokiškio apskrityje 1944-1953 m., w: Rokiškis: miestas, kraštas, žmonès, Vilnius 1999, s. 277-320; Idem, Sovietu teroras ir tautos pasipriešinimas 1944-1945 metais Lietuvos SSR NKVD Kovos su banditizmu skyriaus $1946 \mathrm{~m}$. pradžios statistiniu duomenu dokumente, Lietuvos istorijos metraštis, 1998, Vilnius 1999, p. 241-249.

15 V. Stravinskiene, Lenkai Lietuvoje. 1944 m. antroji puse - 1946 metai: tarp pasirinkimo likti ar išvykti $\dot{i}$ Lenkija, Lietuvos istorijos metraštis. 2004-2, s. 115-134; Idem, Lenku repatriacija i Lenkija: 1944-1947 metai, Istorija, 2006, nr. 63, s. 34-44.

16 СССР И ЛИТВА в годы мировой войнь, т. 1. СССР и Литовская Республика (март 1939 - август 1940 ге.) Сборник документов (Составили - А. Каспаравичюс, Ч. Лауринавичюс, Н. Лебедева), Vilnius 2006, 774 s. 
niało. Uzupełniono również ogólną wiedzę o przebiegu Holocaustu na Litwie, o litewskich prohitlerowskich formacjach wojskowych w latach 1941-1944, o działalności „czerwonych” partyzantów na Litwie, o ruchu oporu wobec okupantów (nazistowskich i sowieckich).

Wspominając o drugim programie należy podkreślić, że z powodu problemów z finansowaniem były kłopoty z jego realizacją. Zaplanowany został jako seminarium międzynarodowe, ale finansowane ze środków własnych uczestników i organizatorów. Nie doczekano się pomocy ze strony fundacji specjalistycznych. Można konstatować, że zgodnie z wytycznymi programu zostały zorganizowane trzy seminaria międzynarodowe (w Wilnie, Liuneburge (?) i w Wigrach w Polsce) na temat „Stosunki większości i mniejszości na Wileńszczyźnie i w regionie Białegostoku w okresie drugiej wojny światowej". W seminariach udział wzięli historycy z Niemiec, Polski (Filia IPN w Białymstoku) a także pracownicy LIH. Niestety, materiał z tych seminariów nie został dotychczas opracowany. Planowane jest jeszcze jedno spotkanie, na którym zostaną wyciągnięte wnioski z dotychczasowego etapu pracy i wytyczone dalsze kierunki badań.

\section{Perspektywy}

Badania przeprowadzone w LIH w latach 2000-2005 pokazały, że nie została jeszcze zbadana sytuacja litewskiego niższego aparatu administracyjnego w okresie drugiej wojny światowej i jego stosunki z organami władzy okupacyjnej; specjalnej uwagi wymaga życie kulturalne oraz ekonomiczne na Litwie w warunkach okupacji hitlerowskiej. Badania w tym kierunku powinny być prowadzone przez okres około trzech lat. Poza tym wciąż brak odpowiedzi na pytania o Holocaust; niedokończone zostało seminarium międzynarodowe, poświęcone stosunkom międzyetnicznym na Wileńszczyźnie (we Wschodniej Litwie) oraz w Polsce w okresie wojny przy zmieniających się okupacjach. Wszystkie uczestniczące w nim strony są gotowe do kontynuacji prac; dodatkowy wkład w realizacje programu powinny wnieść badania okresu sowieckiego z lat 1940-1941, które obecnie realizuje jeden z doktorantów Instytutu. Koniecznie należy dogłębniej zbadać okres ponownej okupacji sowieckiej (1944-1945). Należy bardziej konkretnie zbadać sam proces zamiany okupacji hitlerowskiej na sowiecką oraz procesy emigracji z Litwy. Potrzebne są dalsze badania kwestii litewskiej na arenie międzynarodowej, co jest możliwe przy dalszej współpracy z Moskiewskim Instytutem Historii Społecznej (przy przygotowaniu do druku 
tomu dokumentów, poświęconych spojrzeniu ZSRR na problem Litwy w latach 1940-1945).

Uogólniając, należy podkreślić, że zrealizowane w latach 2000-2005 i nadal prowadzone badania w LIH dają nadzieję na realne perspektywy wspólpracy w ramach wspólnych projektów. Być może uda się znaleźć możliwość rozszerzenia współpracy LIH z badaczami z Białegostoku. Mam tu na myśli możliwość dołączenia do omówionych tutaj projektów drugiego programu LIH, obok historyków z białostockiej filii IPN, także naukowców z Instytutu Historii Uniwersytetu w Białymstoku. Mam nadzieję, że wzbudziłem zainteresowanie historyków uniwersyteckich podobnymi pomysłami.

\section{The research on World War II in the Lithuanian Institute of History in 2000-2005: problems, results and perspectives}

\section{Summary}

The research carried out in the Lithuanian Institute of History in 2000-2005 showed that the situation of the Lithuanian lower administrative apparatus during World War II and its relations with occupational authorities has not been examined yet; special attention should be paid to cultural and economic life in Lithuania during Nazi occupation. Such research should be carried out for at least three years. Moreover, we still do not have answers to the questions about the Holocaust. The international seminar on inter-ethnic relations in the Vilnius Area (Eastern Lithuania) and Poland during the war with changing occupations has not been completed. All the participants of this seminar are ready to continue their works. The research on the Soviet period of 1940-1941, which is now being realized by one of the doctoral students of the Institute, should additionally contribute to the realization of the program. By all means the period of repeated Soviet occupation (1944-1945) requires more profound research. What is more, the process of the exchange of Nazi occupation into the Soviet one itself as well as the processes of emigration from Lithuania should be more comprehensively examined. Further research on the Lithuanian issue in the international arena should be continued, taking into consideration further cooperation with the Moscow Institute of Social History (namely in preparing the volume of documents devoted to USSR's perception of Lithuania's issue in 1940-1945 for publication).

\section{Исследования второй мировой войны в Институте истории Литвы в 2000-2005 гг.: проблемы, результаты, перспективы \\ Резюме}

Исследования, проведенные в Институте истории Литвы в 2000-2005 гг., показали, что не была еще исследована ситуация литовского административного аппарата низшего уровня в период второй мировой войны и его отношения 
с органами оккупационной власти; требуется особое внимание к культурной и экономической жизни в Литве в условиях гитлеровской оккупации. Исследования в этом направлении должны вестись в течении приблизительно трех лет. Кроме этого, все еще нет ответа на вопросы о холокосте; незаконченым остался международный семинар, посвещен межэтническим отношениям на Виленщине (в восточной Литве) и в Польше в период войны при изменяющихся оккупациях. Все участвующие в нем стороны готовы продолжать работу. Добавочный вклад в реализацию программы должны внести исследования советского периода 1940-1941 гг., в настоящее время реализованные одним из докторантов Института. Обязательно нужно более глубоко исследовать период повторной советской оккупации (1944-1945), более подробно исследовать сам процесс замены гитлеровской оккупации советской, а также процессы эмиграции из Литвы. Необходимы дальнейшие исследования литовского вопроса на международной арене, имея в виду дальнейшее сотрудничество с Московским институтом общественной истории (конкретно при подготовке к печати тома документов, посвещенных взгляду СССР на проблему Литвы в 1940-1945 гг.). 